\title{
Predestinasi
}

Volume 13, No. 2, Desember 2020, Hal. 67- 78

ISSN (Print): 1978-9351

\section{Dialogue Concerning Life: Abiogenesis, Biogenesis Or Creationism: Religious Response}

\author{
Peter O.O. Ottuh \\ Dept. of Religious Studies and Philosophy \\ Delta State University, Abraka, Delta State, Nigeria \\ *e-mail: pottuh@delsu.edu.ng; ottuhpeter@gmail.com
}

\begin{abstract}
Life itself is a mystery, the how and when of life's origin constitute a serious challenge to both religion and science. To the reasoning mind, the origination of life is an intellectual problem that needs intellectual resolution especially in the domains of science and religion. To this extent, some scientific assumptions and postulations concerning the origin of life and the universe are found in a number of theories such as evolution, biogenesis, and abiogenesis among others. Obviously, all these theories pose serious challenges to most religious beliefs including the notion of creationism. In this paper, the historical and critical analytic methods were used to document and evaluate the various religious responses on the subject. The paper posits that religious adherents should acquit themselves with authentic religious beliefs and integrate them with authentic scientific knowledge.
\end{abstract}

Keywords: Life; Dialogue; Abiogenesis; biogenesis; Creationism; Religious Response.

\section{INTRODUCTION}

There is a rational interplay between the domain of science and religion (or theology) which is a long time has been a subject of academic discourse among religious, philosophical and theological scholars. Such debates have attempted to proffer answers to such questions whether science and religion are compatible with one another or whether religious convictions once in a while are helpful in postulating science in a logical and rational way. However, the crossdisciplinary domain of scientific and religious studies or theological studies is aimed towards finding answers to these questions.

One puzzle about life on earth is about how it originated. This paradox about life has become an inevitable dilemma that has existed for decades and resulting in serious debates among theists and atheists, philosophers and scientists. Interestingly, various religious groups or sects and scientists have their own postulations or explanations on how life was created or originated. However, while no monistic and acceptable scientific or religious solution has been offered, some scholarly debates and experiments have been undertaken to know whether life emerged through creationism or abiogenesis.

It has become imperative to discuss and examine the historical origin of life on the physical earth including the life that we human live now. One of the challenges facing religions today is the inability to discuss prevailing frontier subjects such as evolution and biogenesis among others in a context that is devoid of antievolutionary apologetics (Venema, 2014). Abiogenesis is a 
scientific field which discusses how life originated from natural order with the aid of earthly substance. Strictly speaking, even though abiogenesis is a science subject, it cannot be devoid of supernatural or natural explanations.

The former is God or some supernatural powers and the latter, the natural laws that govern the created order (Edet 2009; Asira \& Francis 2012). This scientific claim has been at a variant with the doctrine of creationism - a belief system that asserts that life originated through creation by a possible intelligent being or power, hence life's origin that is devoid of any intelligent force cannot be possible. Creationism is mainly championed by theistic religions. Hence, abiogenesis as an anti-creationist concept or theory has far-reaching implications for various religious beliefs in the world.

With probable fraternity between religion and science as a focus, this paper also attempted possible answers to such questions. Thus, it discussed the relations that exist between science and religion using the far-reaching implications of abiogenesis discourse for religious beliefs as a case study. Here, the implications and rationality of abiogenesis for some religious traditions and concepts, including Buddhism, Christianity, Islam, and Hinduism amongst others were discussed. DEFINITION AND DESCRIPTION

\section{Life}

There is no one universally accepted definition of life thus making all biological or scientific definitions of life to be more descriptive. Furthermore, apart from its scientific complexity in term of definition or description, the word, in the contexts of philosophy and religion is also difficult to define or describe (Jeuken, 1975; Duke \& Okafor 2020). The word "life" is from the Greek word "bio." The word "Life" technically means a feature of something that reinforces its living or existence in a physical environment. In this sense, life is existence in the tangible world, the quality that makes living animals and plants different from dead organisms and inorganic matter (Bonner, 2008). On the other hand, life is a term used to summarize the activities that characterize all organisms ranging from such primitive forms as cyanobacteria (formerly known as blue-green algae) to plants and animals (Bonner, 2008). These activities fall into two major categories: reproduction and metabolism. The mechanism of reproduction is now known to be controlled by the properties of certain large molecules called nucleic acids.

Deoxyribonucleic acid (DNA) constitutes the hereditary material that can be passed from one cell or organism to another because DNA molecules can make copies of themselves by means of a process known as template replication (Bonner, 2008). The DNA molecule consists of a long series of coded messages capable of directing the synthesis of specific proteins at any time in the cell or life cycle. In turn, these proteins are responsible for the synthesis of many other substances within the living organism. Reproduction, therefore, involves making copies of the molecules constituting an organism and ultimately results in copies of the organism itself. Even though a concise definition of life is difficult, but in a rough sense, it can be described as an organism that is considered alive on the ground that both metabolism and reproduction are active. The only exceptions to the above description of life are viruses that possess the replicating nucleic acids but lack the ability to convert energy.

One of the central questions about life is how it originated. The generally accepted theory about this is that early in the history of the earth some system of replication powered by external sources of energy must have been formed (Abdollahi1, 2018). A further assumption is that the Darwinian principle of natural selection soon began to play an important role in this process, favouring those replicating molecules that could find energy most readily (Behe, 1996). Such an assumption is reasonable because evolutionary success through natural selection is measured in terms of the ability of a living system to perpetuate its replicating molecules or genes. Thus, primitive systems capable of carrying out the metabolic processes necessary to perpetuate their 
genes had a competitive advantage and eventually evolved into cells. The changes that have taken place since the origin of the cell, that is, the rise of prokaryotes, nucleated cells, multicellular organisms, and, ultimately, higher plants and animals - also thought to have occurred as a result of natural selection (Lamoureux, 2012). Given such an evolutionary progression, it is possible that parallel evolution could have occurred on other planets in the universe.

\section{Biogenesis}

Biogenesis is the origination of living organisms from other pre-existing life. Simply put, biogenesis is the scientific theory of life's origin - postulating the view that only living things can give life to other living things (Orgel, 1998). Biogenesis is a refined form of abiogenesis (life originates from non-life or inorganic matters). The word (Biogenesis) was first coined by Henry Bastian to mean the origination of life from inorganic matters but it was however, refined by Henry Huxley to mean the origination of life from living matters (Schopf, Kitajima, Spicuzza, Kudryavtsev \& Valley, 2018; Orgel, 1998). In this sense, it is impossible for non-life to beget another life through spontaneous generation.

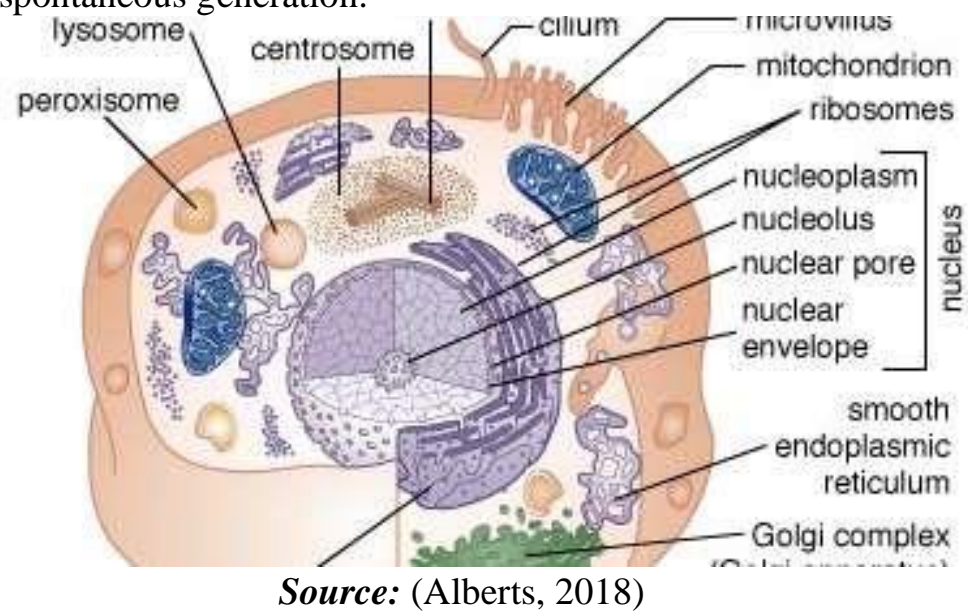

Figure 1: Demonstrating the principle of biogenesis

In its strict sense, the theory of biogenesis is essentially associated with the works of Louis Pasteur indicating that complex living organisms only originate uniquely from other living organisms through proliferation (Strick, 2001). This postulation is summarily expressed in Latin as Omne vivum ex vivo (life comes from life) (Orgel, 1998). The variance of biogenesis is abiogenesis also called spontaneous generation.

\section{Abiogenesis}

Thomas Huxley, a foremost proponent of Darwinism was the first to coin the term "abiogenesis" in the year 1870 (Greear, 2020). However, abiogenesis as a scientific and evolutionary theory was popularized by Stanley Miller when he tried to prove the origin of life from inorganic origin through his famous experiments. Abiogenesis has its root in the cone Greek "a-" meaning "not" and "bios" which mean "life" and "genesis" meaning "origin or beginning". Technically speaking, abiogenesis implies the origin of life from a non-life (Greear, 2020). Abiogenesis may also mean, "Absence of biological origin" (that is, the opposite of "biogenesis"). In other words, the process whereby organic molecules are created by forces outside a living organism is called abiogenesis. In this sense, organisms are believed to easily create relative carbon-carbon bonds resulting from enzymes with strong energy. Early scientists, predicated their arguments on the above claims to contend the theory of evolution since it was not scientifically 
clear to ascertain whether non-organic sources are capable of producing organic molecules (Maclachlan, 2014).

Other phrases used to refer to abiogenesis by scientists are "non-biologic origin" and "spontaneous generation of life" or "formation of life from inorganic matter" where both phrases imply "life from non-life (Harris, 2002). In this sense, if life originates from non-life as it is postulated, then uncontrolled raw chemistry would be capable of making sophisticated and multipurpose machines to perfect the techniques that would make biogenesis realizable (Kenyon, 1982). Statistics from historical records have shown that one of the problems associated with Darwinian Theory of Evolution is the improbability of the spontaneous formation of life (Behe, 1996; Swiezynski, 2016). Here, Darwinian "natural selection" cannot serve as an option or part of the process that originates life. Abiogenesis is a procedure by which inorganic material paves the way to earthly life; there are still disagreements between scientists on what constitutes a valid scientific explanation of the phenomenon of the origin of life (Ruffinengo \& Walsh, 2021).

Abiogenesis being an ancient theory holds that certain lower forms of life, especially the insects, reproduce by physicochemical agencies from inorganic substances. This view went contradicted until after the middle of the 17th century when the Italian physician and poet Francesco Redi disproved (1668) the prevailing notion that the maggots of flies were generated in putrefying meat exposed to air. In 1768, the Italian naturalist Lazzaro Spallanzani further showed that microorganism-containing solutions that were boiled and then sealed off would remain free of microorganisms thereafter; and in 1836 the German naturalist Theodor Schwann provided additional proof with still more meticulous experiments of this nature.

In a broad sense, abiogenesis is loose parts of the Darwin theory of evolution in the sense that a living organism or matter is believed to originate at a point from inorganic matter through normal chemical and physical means (National Academy of Sciences, 2019). Calculating the probability of this chemical process may prove difficult, but using an estimate rooted in logical presuppositions may be possible (Ferris \& Fry, 2001). For example, nucleic and amino acids which manifest in dual forms are considered to be life's moulding pillars, and every life has only one of these forms. Thus, all two forms are products of inorganic chemical mechanisms; hence, it is difficult to believe that life did not emanate from just one form. It is imperative; therefore, that life on earth must originate from a wide range of forms equally.

Some curious scientists have speculated that Ribonucleic Acid (RNA) (a nucleic acidcontaining ribose found in all living cells, essential for protein synthesis) molecules are the first self-replicating molecules (Ferris \& Fry, 2001). Thus, most RNA molecules possess the power to catalyze the generation of novel RNA molecules as indicated in the ribosomes of every life on earth. As time goes on, the RNA molecule acquires genetic changes which permit its synthesis of a protein that eventually afterwards lead to the production of more RNA (Harris, 2002). Additionally, further mutations occur and cause the creation of proteins used in synthesizing the strands of Deoxyribonucleic Acid (DNA) from RNA leading to the birth of the genome of an organism in a contemporary context. However, many scientists who study abiogenesis have contended about the transitory point between abiogenesis (inorganic matter as life's source) and biogenesis (living organism as life's source).

\section{Creationism}

Creationism is a broad range of beliefs involving an appeal to God's miraculous intervention to explain the origin of the physical universe, life and the divergent plants and animals on planet earth. Proponents of creationism are called "creationists". They invoke divine intervention to explain some of the phenomena of creation even though, they do not necessarily agree on a monolithic explanation about creation. In the second half of the 20th century, the most 
visible and politically active creationists maintained that the entire universe was created within the past 6000 to 10,000 years (Numbers, 2002; 2008). Prior to Charles Darwin's On the Origin of Species published in 1859, some Westerns including well-known scientists have consented to creationists' concept of the universe but not strictly in the real sense of it.

Despite mounting evidence of the great antiquity of life on earth, many adherents of the Christian religion have continued to accept the traditional biblical account of a relatively recent six-day creation in the Garden of Eden which culminated in the appearance of Adam and Eve. Writing in 1852, American commentator William B. Hayden estimated that one-half of the Christian public remained loyal to the traditional view; the other half had adopted one or the other of two popular reinterpretations of the creation account in the biblical book of Genesis (Mojzsis, 2001). The above reinterpretations permitted Christians to accept the accumulating paleontological (Paleontology - the study of life in prehistoric times by using fossil evidence) evidence without abandoning their faith. The first was the so-called Day-Age theory, according to which the six days of the biblical creation in Genesis 1:1-2:4 represented vast geological ages rather than 24-hour periods (Abdollahi1 \& Abdollahi, 2018). The rival reinterpretation, known as the Gap theory, allowed for an immense interval between initial creation and the creation of the Garden of Eden in about 4,000 BC.

In scientific circles, at least three competing versions of creationism circulated during the first half of the 19th century (Shiller, 2004). One version was espoused by Carolus Linnaeus, a Swedish naturalist who loosely followed the biblical story in proposing the simultaneous creation in one location of single pairs of animals, who then multiplied and migrated to their eventual homes (Wickramasinghe, 2010). By contrast, Charles Lyell, an English geologist advocated the notion of multiple centres of creation established at various times and in different places (Stockwell, 2002). A third view was held by Louis Agassiz, a Swiss-American naturalist who denied that species originated in single pairs, whether at one or multiple locations (Avery, 2014; Shiller, 2004; Christie, 2019). Agassiz argued instead for the simultaneous creation of multiple individuals in each species with all distributed over the ranges God meant for them to inhabit. All three of these views, and especially the last two, allowed for Earth's history to extend far beyond 6,000 years.

Asa Gray affirmed that the Bible taught "an orderly progress from lower to higher forms of matter and life" (cited in Schulze-Makuch \& Irwin, 2006 p.137) yet he insisted that the first humans had come "into existence as the Bible represents, by the special creation of a single pair, from whom all the varieties of the race have sprung" (p.154). About 1970 the adherents of flood geology, hoping to gain a forum in the public schools, stripped their theory of its biblical references and called it scientific creationism or creation science. Instead of trying to outlaw the teaching of evolution, as creationists have done in the 1920s, the creation scientists sought equal time in school curricula for their views (Schulze-Makuch \& Irwin, 2006). In the early 1980s, two states, Arkansas and Louisiana, passed laws mandating the teaching of creation science whenever evolutionary theory was taught in public schools (Numbers, 2002; Avery, 2014). In 1987 the U.S. Supreme Court declared such laws to be unconstitutional intrusions of religion in the public schools (Numbers, 2008). Despite this setback, creationists have not abandoned their efforts to persuade local school boards to permit the teaching of creationism in the United States' public schools. The doctrine of creation first, sees God creating the world out of nothingness (ex-nihilo) (Mondal, 2017). Second, God is distinguished from the physical universe - this connotes the concept of pantheism or its renewed format called Panentheism. God as a rational and independent being is believed to have created universe freely (Jaeger, 2012b; 2012a). Lastly, the creationism holds that creation is imperatively perfect (Genesis 1 ).

\section{Religious Response}


72 Predestinasi
Volume 13, No. 2, Desember 2020 Hal. 67- 78

\section{Islam}

The Islamic faith which is monotheistic came into existence in the $7^{\text {th }}$ century as a result of the series of revealed messages from God (Allah) to Prophet Muhammad (Dhanani, 2002; Edet 2019). Islam apart from its etymological meaning also implies "geopolitical systems", which incorporates caliphates and empires that have been primarily based with the aid of Muslim leaders from the $7^{\text {th }}$ century onward, such caliphates as that of the Umayyad, Abbasid, and Ottomans. In addition, Islam implies a path of existence that flourished inside this politico-spiritual context of its own logical and rational traditions (Dhanani, 2002). One of its significant distinctive characteristics is its notion of a mono-God (called Allah), who communicated via prophets such as Adam, Abraham, and Muhammad amongst others (Kahane, 2011; Ottuh \& Jemegbe, 2020). The nexus between the Islamic faith and science is a complicated one.

Many Islamic faithful and nations are proponents of pseudo-scientific ideologies, for instance, the notion of "old earth creationism", "creation of human bodies on the day of resurrection from tailbones", "treatment of pains with serious prayers in place of medical treatment" (Guessoum, 2009 pp. 4-5; cf. Malpas, 2017). Present-day lack of interest in the prominence of science in Islam may be due to the fact that Islamic nations have exceedingly advanced far above the cultures of Europe in the $9^{\text {th }}$ and $15^{\text {th }}$ centuries thus, progressing in the areas of mathematics, astronomy, optics, and medicine.

The question is: since Islam existed before the beginning of abiogenesis and even evolution what will be its response to the perception of life's origin including that of humanity.

For some Muslims, abiogenesis is a pseudo-science. But they believe that the mythical records concerning the first humans - Adam and Eve in the Qur'an (2:30-39, 7:11-25, 15:26-44, 17:61-65, 20:115-124 and 38:71-85) are exceedingly authentic. It is stated in the Qur'an (36:36) that a mixture of soil and water found on the earth formed the material from which human beings were created or originated.

Additionally, not only humans were created from the earth material, but also pairs of all living organisms on earth (Qur'an 36:36). For Muslims, the scientific enterprise of investigating into the origin of life on earth is a mandate from God. This is evidence in the Qur'anic injunction that says:

Have they not considered how Allah begins creation and then repeats it? Indeed that, for Allah, is easy. Say, travel through the land and observe how He began creation. Then Allah will produce the final creation. Indeed Allah, over all things, is competent (29:19-20).

In the actual sense of it, the Qur'an rarely talks about creation in the context of ex-nihilo (out of nothing) rather it talks about creation in the context of in-nihilo (out of something). The question is could it imply that this concept of creation connotes abiogenesis or biogenesis because the clay or the earth mixture implies typical inorganic material or matter. In this sense, the Qur'an is suggestive of the fact that life has its origin in inorganic matter or source. Here, the Qur'anic postulation is considered to be compatible with the scientific theory (abiogenesis) that states that a non-living organism is the source of life on earth.

\section{Christianity}

Christianity which was developed during the 1st century AD from Judaism by some followers of Jesus is monotheistic in nature. The relationship that exists between religion and science is measured by the interpretative understanding of its sacred scripture (Allam 2018; Savarirajan \& Fong, 2019). Viewed from its context, everything on earth is perceived as the "created order" and God as the Creator. This perspective is capable of assisting the development of valid Christian notion on some contestable scientific theories about the universe including such concepts as the origin of life on earth (Edet 2011). The Christian worldview is rooted in the belief 
that everything on earth was created by God within the space of six days with only humans being created God's own image (Imago Dei) (Moritz, 2011; Hauptman, 2013). Worthy of note is the fact that Christians do not need empirical verification or evidence to prove that God is the originator or creator of everything on earth rather they acknowledge this by faith (Hebrews 11:6, 13 ) and at a posteriori level.

Science totally rejects the notion put forward by creation science as standing outside the scopes of a legitimized scientific thinking (Scott \& Cole, 1985; Alston, 2003; Montgomery, 2012; Capra, 2014). In other words, creationist notion premised on the principles of science is rejected due to its alignment with biblical doctrines and unempirical testability. The arguments of creation science and Christian Science concerning the origin of life and the universe are predicated on $a$ priori presuppositions that revolve around naturalism and uniformitarianism even though they are still under contentions (Nye, 2014). Thus, the proponents of creation science do not appeal against applying naturalistic or uniformitarian, assumptions, but most times only point out the areas of scientific theories that conflict with shared religious beliefs (Capra, 2014).

Some scientists who argue for abiogenesis does so base on experiments undertaken which prove, for example that:

i. Insect larvae originate from rotting meat.

ii. Frogs originate from mud after rainfall.

iii. Flies originate from animal manure (Kahane, 2011).

However, counter-arguments based on Louis Pasteur's experiment has revealed that it is only living microorganisms that can originate living microorganisms (cited in Mondal, 2017). The result of Pasteur's experiment debunks the hypothesis which holds that inorganic matter can originate organic matter or life. Thus, the above exposition has assisted in the resolution of the disagreements between abiogenesis and biogenesis and at the same time, has helped in connecting the two concepts in a biblical context (Hauptman, 2013). Charles Darwin himself also thought about this subject when he advocated the creative power of God - a creator of life who used natural methods and who is far greater than a force that relies on some magico-divine creative acts (Lamoureux, 2012; Miño \& Espinosa, 2015; Stump, 2020). It is further argued that bioevolutionary notion need not threaten teleological notion and the development of life-based on divine intention. Hence, it invalidly transfers God's creative power to the underlying creative power of 'laws'.

There is a theological problem arising from the incomprehensible notion of how life originated on earth. The relation of theological concepts of "creation-continua" to "explanation of continuity" in the language of science presents an imperative reason for more investigation into the subject (Stump, 2020; Stump, Eleonore \& Padgett, 2020). This kind of thinking rests on an evolutionary framework whose authentic aims are relationship, continuation, and model and not proportionality and finite classifications (Boring, Stump \& Freeland, 2020). The above scenario is not suggestive of Christian attestation to or acceptance of life's origination from non-life that is called "abiogenesis" in its scientific sense.

\section{Hinduism}

Hinduism is a polytheistic religion that started in $500 \mathrm{BCE}$ and has varieties of religious and philosophical traditions to its credit (Hackett, 2015). Unlike some of the monotheistic faiths, it has no known distinctive stand on the notion of God and creation. Most Hindus are of the view that personal God exists he is immanent in the creation of the universe. This consideration validates the debate on the nexus between science and religion since their (creator and creature) ontological differences do not exist or postulated (Subbarayappa, 2011; Teresi, 2002). Although 
not certain, from an extreme position Hinduism consent to the fact that the universe was ordered. Cosmologically,

Hinduism conceives the notion that humanity or life is a transitive form of Sanskrit (Ancient Indian language). The Hindus believe that Brahma (Supreme Being) is a 'Person' that possess bodily form hence, the entire universe including the organic and inorganic matters are parts of this body. In a common understanding of this, it means that the entire earth and everything in it is regarded to be the body of God. Here, creation is diversified just as the natural human body has different parts. On the whole, in Hindus conception, "purusa" (i.e. body, mind, spirit or consciousness) is the totality of it. Thus, purusa depicts "a Lord of the Universe" which is Hebrew equivalent of "Adam Kadamon" ("the primordial human") in Hebrew theological thought.

The first human being created by God on earth is considered in Hindus cosmology to have arisen from a "model of a cosmic Purusa" (Thero, 2016) and in the 5th verse of the book of Genesis, it is considered as a "yajna" (spiritual sacrifice) a creation that manifests in the fallen cosmos by the gods. Undoubtedly, this is glossily a Vedic sacrifice method align with the created order which also includes yantra (mystical diagram or instrument) and mantra (divine utterance) (Thero, 2016). Hinduism vividly distinguishes between an "ordered cosmos" and "unordered cosmos." In this sense, the Hindus are acquitted with multiple beliefs concerning how life and the universe evolved from a pre-existence of which the beginning and the end are unknown. The Hindus believe that all life on earth emanated as follows:

i. There is a cosmic egg (Brahmanda) from where all life on earth originated (Thero, 2016).

ii. There is a golden embryo (Hiranyagarbha) that originates life.

iii. There exist an indestructible person (Akasapurusa - "vibrating energy") through which all life on earth originate.

iv. There is a creator (Visvakarman), the first fruit from Brahmanda and the architect of the gods.

v. On the whole, the Supreme Being (Brahma) is the chief originator of the universe and everything in it including superintending over them (Stringer, 2012).

vi. That everything on earth emanated from the primordial sacrifice (yajna) explained in the Rig Veda (Dixon, 2010).

vii. That life and the universe have no origin or possibly have their origin from the earth itself or some other source which may be considered to be the Supreme God (Brahman) (Thero, 2016).

\section{Buddhism}

The core belief and aim of Buddhism are to demonstrate the ontological authenticity of beings and the cosmos and guiding them to attain ultimate bliss. Most Buddhists based on assumption believe that science, especially bio-energy scientists have failed to prove the source where life originated from. The explanations regarding the origin of life or beings on earth in Buddhism are majorly spelt out in the Aggannasutta. Here, Buddhists explain life in the universe and other issues associated with it. Additionally, Buddhists' philosophical postulations concerning this subject are also contained in the paticcasamuppada - theory of dependent origination. Most scholars have consented to this view because of its attempt to align with contemporary scientific theory such as biogenesis. For example, the theory of evolution in the sense of scientific principle is authentically accepted in the Buddhist Agannasutta (Abeynayake, 2013). However, some other scholars who do not consent to the Buddhist theory consider it unscientific.

However, Buddha the founder of the religion responded to this puzzle by explaining that the origin of life is "Abassara-kaya" (a place far away from the universe - the world of Brahma). 
According to Buddha, beings have their origin in the Abhassara (the world of Brahma) (Sugunasiri, 2014; Sollereder, 2015). These beings are believed to possess the features of the conscious mind, self-luminous, feeding on delight, and migrating in the air gloriously. According to Buddha, the beings duel in that states for $a$ long period before the Brahma world starts its further expansion.

Many scientists have explained how life originated using the instruments of biochemistry and organic chemistry. With these scientific findings, it is discovered that the different objects on earth actually came from another world (Malpas, 2017; Street, 2006). However, there is no scientific census as this matter is concerned. But some of the questions such as how, when and why life did originate from a world beyond the universe have remained unanswered by scientists. But Buddhism has attempted to give answers to these and many other questions.

Within the Buddhist philosophical context, Buddha attempted an explanation of the origin of life through a cosmological model where he posited that the universe is capable of expanding and contracting over time. This Buddhist view of expanding and contracting model tends to align with the "Big Bang Theory" of Fred Hoyle which states that the universe expands and contracts because at a time, it is "extremely compact, dense, and hot (Schliesser, 2012). In Buddhist conception, the radiant bodies emanating from Abbassara world are considered to be similar to molecules like bacteria which can migrate through water and air. So, it can be concluded that the beings mentioned in the Buddhist Aggannasutta are similar to plasma (cells). Biologically, every cell has life hence; it can originate another life (Savarirajan \& Fong, 2019). Based on this, one can argue that the Buddhist conception about the origin of life is suggestive of biogenesis - life begets life, not abiogenesis nor creationism.

\section{CONCLUSION}

In this paper, the scientific theories of abiogenesis and biogenesis concerning the origin of life on earth have been examined in relation to creationism. The religious explanations to the claims of these theories by some selected religions and groups were also examined and evaluated. In response, most theistic religions (e.g. Christianity, Islam, Judaism, Hinduism, etc.) and nontheistic religions (e.g. Buddhism, Taoism, etc.) subscribe to the notion of biogenesis - that life has its origin in another life (life begets life). On the other hand, these religions also attribute the origination of life and everything in the universe to the supernatural act of creation although with diverse assertions or versions of creationism. For example, among the Abrahamic religions (Christianity, Islam, and Judaism) the stories of creation are similar as reflected in the biblical accounts of Genesis (Asuquo 2019; Eyo 2019). This book chronologically gives the accounts of how the whole universe and everything in it was created in just 6 days including human life.

However, Christian Science and creation science in their varied assertions concerning the origin of life and the universe in the context of creationism seem to consent to both theories of abiogenesis and biogenesis. As regards abiogenesis, their explanations are rooted in the biblical fact that God created the first humans (life) from inorganic matter (dust or sand) and created other things out of nothing. Many Judaizers, Christians and Muslims reject this explanation that points to abiogenesis based on the belief that God himself is life (Giver of life) - a necessary being (life) that exists to make other (contingents) existence (life) possible. The bottom line of these scientific and religious theories is the far-reaching implications and dialectic rationality they have on diverse religious beliefs in human society. It is imperative, therefore, for religious adherents to acquit themselves with their authentic religious beliefs by integrating them with authentic scientific knowledge. Hence, the advice of West (2014) becomes imperative, that adherents should not lose their faith as a result of science. 


\section{REFERENCE}

Abdollahi1, A. and Abdollahi, S. (2018). Creation of the life naturally probable and spontaneous or supernaturally exact and predetermined? American Journal of Mathematics and Statistics 8(1), 22-26

Abeynayake, O. (2013). Buddhist view on the origin and evolution of the society. Retrieve from: http://elearning.ibc.ac.th/sites/default/files/classnote/02_Oliver_Buddhist_View_of_the_ Origin_and_Evolution_of_the_Society.pdf, Access date-October 10, 2014.

Alberts, B.M. (Ed.). (2018). Biogenesis. Encyclopaedia Britannica. Retrieved from:

Allam, O. S. (2018). Unmasking “Alekwu” Religious Experience among the Idoma People-Group of Nigeria. GNOSI: An Interdisciplinary Journal of Human Theory and Praxis, 1(2), 118130.

Alston, J.P. (2003). The scientific case against scientific creationism. Bloomington, IN: iUniverse.

Asira, A. E., \& Francis, E. (2012). Religious appraisal of the human concept in world religions. American Journal of Social Issues \& Humanities, 2(2), 65-72.

Asuquo, O. O. (2019). Humanism as a Category of Religious Alternative. GNOSI: An Interdisciplinary Journal of Human Theory and Praxis, 2(1), 30-36.

Avery, J.M. (2014). Annotated bibliography: Faith, learning and Christian higher education in the twenty-first century. The Christian Librarian 57 (2), 20-41.

Behe, M.J. (1996). Darwin's black box. NY: The Free Press

Bonner, J.T. (2008). Life. Microsoft Encarta [DVD]. Redmond, WA: Microsoft Corporation,

Boring, E., Stump, J.B. and Freeland, S. (2020). Rethinking abiogenesis: Part 1, continuity of life through time. Perspectives on Science and Christian Faith 72 (1), 25-35.

Capra, F. (2014). The systems view of life: A unifying vision. Cambridge: Cambridge University Press.

Christie, J.E. (2019). From influence to inhabitation. Science 228, 17.

Dhanani, A. (2002). Islam. In Fengren, G.B. (Ed.). Science and religion: A historical introduction (pp. 73-92). Baltimore and London: Johns Hopkins University Press.

Dixon, T., Cantor, G. and Pumfrey, S. (Eds.) (2010). Science and Religion: New historical perspectives. Cambridge: Cambridge University Press.

Duke, E. O., \& Okafor, J. O. (2020). Poverty Alleviation Policies of Selected Churches in Anambra State, Nigeria. GNOSI: An Interdisciplinary Journal of Human Theory and Praxis, 3(1), 40-52.

Edet, F. F. (2009). The concept of God in African traditional religion. Sophia: An African Journal of Philosophy, 12(1), 127-135.

Edet, F. F. (2011). The contribution of religion to national development: A case study of living Faith church aka Winner Chapel. Sophia, 10 (2), 91-97

Edet, F. F. (2019). Dress code for women in Islam: a sociological investigation. Lwati: A Journal of Contemporary Research, 16(3), 182-188.

Eyo, U. E. (2019). The Parable of the Talents and Economic Management: Lessons for the Nigerian Nation. GNOSI: An Interdisciplinary Journal of Human Theory and Praxis, 2(2), 55-63.

Ferris, J.P. and Fry, I. (2001). The emergence of life on earth: A historical and scientific overview. Cape Town: Kluwer Academic Publishing.

Greear, D. (March, 2020). Abiogenesis. Weekly News Digest. Retrieved from: https://biologydictionary.net/abiogenesis/.

Guessom, N. (2009). Islam's quantum question: Reconciling Muslim tradition and modern science. London and New York: Tauris. 
Harris, H. (2002). Thinks come to life: Spontaneous generation revisited. Oxford: Oxford University Press.

Hauptman, A. (2013). Integrating faith and science. InterVarsity News. Retrieved from: https://intervarsity.org/news/integratingfaith-and-science.

Hauptman, A. (2013). Integrating faith and science. Retrieved from http://www.intervarsity.org/news/integrating-faith-and-science.

Jaeger, L. (2012a). Against physicalism plus God: How creation accounts for divine action in nature's world. Faith and Philosophy 29, 295-312.

Jaeger, L. (2012b). What the heavens declare: Science in the light of creation, eugene. OR: Wipf and Stock.

Jeuken, M. (1975). The biological and philosophical definitions of life. Acta Biotheoretica 24 (1\&2), 14-21.

Kahane, G. (2011). Evolutionary debunking arguments. Noûs 45, 103-125.

Kenyon, D. (1982). What is creation science? London: Creation-Life Publishers.

Lamoureux, D.O. (2012). Darwinian theological insights: Toward an intellectually fulfilled Christian theism. Part 1: Divine creative action and intelligent design in nature. Perspectives on Science and Christian Faith 64 (2), 108-120.

Lipka, M. (2016).Why America's 'nones' left religion behind. Fact Tank. Pew research Center. Retrieved from: http://www.pewresearch.org/facttank/2016/08/24/why-americas-nonesleft-religion-behind/.

Maclachlan, R. (2014). Abiogenesis? New Zealand Geographic 126, 28. Retrieved from: https://creation.com/abiogenesis

Malpas, J. (2017). Religion and science. The Stanford encyclopedia of philosophy. Retrieved from: https://plato.stanford.edu/archives/win2012/entries/davidson.

Mojzsis, S. J. (2001). Life and the evolution of earth's atmosphere. In Mathes, E. (Ed.). Earthinside and out (PP. 32-39). New York: New Press.

Mondal, P. (2017). Origin of life: Five ancient theories of origin of life. Retrieved from: https://www.yourarticlelibrary.com/biology/origin-of-life-5-ancient-theories-of-origin-oflife/13248.

Montgomery, D.R. (2012). The rocks don't lie: A geologist investigates Noah's flood. Indiana: Norton.

Moritz, J.M. (2011). Evolution, the end of human uniqueness, and the election of the imago dei. Theology and Science 9, 307-339.

National Academy of Sciences (2019). Abiogenesis. Proceedings of the national academy of sciences 93 (19):10268-10273

Numbers, R.L. (2002). Creationism since 1859. In Ferngren, G.B. (Ed.). Science and religion: A historical introduction (pp. 261-292). Baltimore, MD: John Hopkins University Press

Nye, B. (2014). Undeniable: Evolution and the science of creation. Enugu: St. Martin's Press.

Orgel, L.E. (1998). The origin of life - a review of facts and speculations. Trends Biochemistry Science 23 (12), 491-495.

Ottuh, P.O.O. (2020). Assessing human reproductive cloning and creationism from the perspectives of Raelianism and African belief. Jurnal Office 6 (1), 81-96.

Ottuh, P.O.O. and Jemegbe, M.O. (2020). Communication in religion and its integrative implications for society. Pinisi Discretion Review 4(1), 1-10.

Paz-Y-Miño-C, G. and Espinosa, A. (2015). Evolution controversy: A phenomenon prompted by the incompatibility between science and religious beliefs. The International Journal of Science in Society 7(2), 1-23. 
Ruffinengo, M. and Walsh, A. (2021). Ideology in biology theism meets atheism in the case of abiogenesis. Journal of Religion and Society 23, 3-21. Retrieved from: http://moses.creighton.edu/JRS/toc/2021.html

Savarirajan, D. and Fong, S. (2019). Bridging bible and biology: The impact of faith integration on the spiritual growth of students in Christian higher education. Journal of Instructional Research 8 (1), 231-255.

Schliesser, E. (2012). Newton and Spinoza: On motion and matter (and God, of course). Southern Journal of Philosophy 50, 436-458.

Schopf, J. W., Kitajima, K., Spicuzza, M.J., Kudryavtsev, A.B. and Valley, J. W. (2018). SIMS analysis of the oldest known assemblage of microfossils document their taxon-correlated carbon isotope compositions. PNAS 115 (1), 53-58.

Schulze-Makuch, D. and Irwin, L.N. (2006). Life in the universe: Expectations and constraints. Springer, Berlin: Heidelberg.

Scott, E.C. and Cole, H.P. (1985). The elusive basis of creation science. The Quarterly Review of Biology 60 (1), 21-30

Shiller, B.M. (2004). Origin of life: The 5th option. Victoria-Crewe: Trafford Pub.

Sollereder, B. (2015). A modest objection: Neo-Thomism and God as a cause among causes. Theology and Science 13, 345-353.

Stockwell, J. (2002). Borel's law and the origin of many creationist probability assertions. Retrieved from: http://www.talkorigins. org/faqs/abioprob/borelfaq.html.

Street, S. (2006). A Darwinian dilemma for realist theories of value. Philosophical Studies 127, 109-166.

Strick, J. (2001). Introduction. Evolution and the spontaneous generation. Grand Rapids: Continuum International Publishing Group

Stringer, C. (2012). Evolution: What makes a modern human? Nature 485, 33-35.

Stump, E. and Padgett, A.G. (Eds.). (2012). The Blackwell companion to science and Christianity. Malden, MA: Blackwell.

Stump, J. (2020). Does God guide evolution? Perspectives on Science and Christian Faith 72 (1), $15-24$.

Sugunasiri, S.H.J. (2013). Devolution and evolution in the Agganna sutta. Canadian Journal of Buddhist Studies 9, 17-104.

Sugunasiri, S.H.J. (2014). Dhamma abroad evolution: A Canonical study of Agganna sutta in relation to science. Toronto: Nalanda Publishing.

Swiezynski, A. (2016). Where/when/how did life begin? A philosophical key for systematizing theories on the origin of life. Cambridge: Cambridge University Press.

Teresi, D. (2002). Lost discoveries. New York: Simon and Schuster.

Thero, L.S. (2016). Origin of the life and the universe-from the Vedic era to modern scientific investigation. International Journal of Science and Research (IJSR) 5 (11), 1885-1895.

Venema, D. (2014). At the Frontiers of evolution: Abiogenesis and Christian apologetics. Retrieved from: https://biologos.org/articles/series/evolution-basics/at-the-frontiers-ofevolution-abiogenesis-and-christian-apologetics

West, J.G. (2014). Are young people losing their faith because of science? Retrieved from: http://www.kmlhs.org/UserFiles/ Servers/Server_738581.

Wickramasinghe, N.C. (2010). The biological big bang: Panspermia and the origins of life. Cambridge: Cosmology Science Pub. 